\title{
Feast or famine? Epipalaeolithic subsistence in the northern Adriatic basin
}

\author{
Preston Miracle \\ Department of Archaeology, University of Cambridge, UK \\ ptm21@cam.ac.uk
}

\begin{abstract}
In this paper I use a late glacial-early postglacial archaeological case study from Istria, Croatia, to develop methods for inferring the social contexts of food consumption from animal remains. A number of lines of evidence are suggestive of an increase over time in the diversity and scale of food consumption at Pupicina Cave. At the scale of the region, these data are consistent with subsistence intensification in response to shortfalls in food resources. At the scale of the site, however, these data can be interpreted as remains from "celebratory" feasts. This paper addresses the gap between theory and method in the identification of prehistoric feasts.
\end{abstract}

IZVLEČEK - S pomočjo živalskih ostankov, najdenih na poznoglacialno-zgodnje postglacialnem najdišču v Istri na Hrvaškem, razvijemo metode za ugotavljanje družbenega konteksta uživanja hrane. Številni dokazi kažejo, da sta se v jami Pupićina sčasoma povečala tako raznolikost kot tudi obseg uživanja hrane. V regionalnem merilu se ti podatki časovno ujemajo z zaostrenimi pogoji preživljanja zaradi pomanjkanja virov hrane. V okviru najdišča lahko te podatke razložimo kot ostanke "prazničnih" pojedin. V članku usmerimo pozornost tudi na razkorak med teorijo in metodo pri identifikaciji prazgodovinskih pojedin.

KEY WORDS - Mesolithic; Upper Palaeolithic; zooarchaeology; feast; hunter-gatherer; Europe

\section{INTRODUCTION}

There has been considerable interest in dietary changes across the Pleistocene-Holocene transition in the old World, especially since Flannery's (1969) proposal of a "broad spectrum revolution" as a precursor to the emergence of agriculture. This dietary shift was generalised and popularised as "The Food Crisis in Prehistory" by Cohen (1977). Cohen, along with many other archaeologists in the 1970s and 1980s, followed Boserup's (1965) lead and focused on population pressure as the prime mover behind these dietary changes. In the last 15 years archaeologists have made great strides in understanding foragers' changing diets and subsistence strategies by using predictive models such as optimal foraging theory (e.g. Bettinger 1991; Kelly 1995). Archaeological applications have ranged from relatively coarse studies of taxonomic diversity (e.g. Neely \& Clark 1993; Miracle 1996) to more complex models of prey choice (Miracle 1995) and sophisticated simulations of predator-prey interactions (Belousky 1988; Winterhalder et al. 1988; Stiner et al. 2000). The common thread running through all of these studies is that people change their strategies in response to resource/population imbalances. In plain language, people take action when their plates are empty, whatever the cause may be.

Resource procurement, distribution, and consumption have certainly played a pivotal role in human evolution, and feeding strategies have been and are under strong selective pressure. There is much more, however, to the consumption of food than the simple conversion of ingested calories into energy for somatic maintenance, growth, and reproduction. Food plays an "active" role in the creation of sociocultural contexts and the negotiations of power 
enacted therein. Food cannot be understood divorced from the social and cultural contexts in which it is produced and consumed. It is as much material culture as are pots and projectile points.

Food and its consumption have often been studied anthropologically in terms of cuisine and feasts (e.g. Appadurai 1981; Douglas 1972; 1984; Goody 1982; Levi-Strauss 1969; 1978; Wiessner \& Schiefenhövel 1996). "Cuisine" commonly refers to food preparation, cooking, "recipes", food presentation, and the food itself. Feasts have been defined as "public ritual events ... [that] provide an arena for the highly condensed symbolic representation of social relations" (Dietler 1996.89). Archaeologists, particularly prehistorians, have been relatively uninterested in food, cuisine, and feasting until recently (e.g. Dietler 1996; Gosden \& Hather 1999; Gummerman 1997; Hayden 1996; Samuel 1996). Food procurement and consumption are widely recognised as key elements of hominid adaptations and strategies during the Palaeolithic and Mesolithic periods. While there has been considerable theoretical work (e.g. Haw kes 1992; 1993; Hill \& Kaplan 1993; Wiessner 1996; Winterhalder 1986) and a few archaeological studies of food sharing (e.g. Enloe \& David 1989), scant consideration has been given to the social contexts and meanings associated with and created by food consumption (see discussion of Mesolithic cuisine in Miracle 2001). A significant exception is Brian Hayden, who has been arguing over the last decade for the importance of the social contexts of food consumption and feasting to two of the "big issues" in the human past, namely the development of food production (Hayden 1990) and emergence of social inequality (Hayden 1995). The goal of this paper is to explore methods for inferring contexts of consumption from food waste in prehistoric huntergatherer sites, particularly with reference to faunal assemblages from the Late Upper Palaeolithic and Mesolithic periods in Pupićina Cave, Istria, Croatia.

Ethnographic evidence of feasting among human foragers has been summarised and discussed by Hayden (1996), who proposed that there are three basic types of feast: celebratory, mutual aid, and commensal. The first two types of feast serve functions of social bonding and risk buffering, and are widely known among hunter-gatherers, whether "simple" (immediate-return) or "complex" (delayedreturn). Celebratory and mutual-aid feasts are treated as by-products of seasonal aggregations of mobile and dispersed populations; the primary functions of these population aggregations are thought to be exchanges of people (marriages), items (raw materials and artefacts), and information (rituals, resource availability). Ethnographically and archaeologically, most interest has been in the associated exchanges rather than in the feasts themselves, even though the labour and food requirements associated with such feasts were often substantial. In this vein, Conkey (1991) suggests that aggregation sites would have been places of increased social activity and fluidity, with many social relationships in a state of flux and/or up for negotiation.

In contrast to celebratory and mutual-aid feasts, commensal feasts are characterised by diacritical display, control over labour, and economic gain. Food and the social contexts of its consumption are central to commensal feasts; ethnographic accounts of the "potlatch" of the Kwakiutl and other American Northwest Coast cultures (e.g. Boas 1966; Codere 1950) figure prominently in the definition of commensal feasts. The labour of kin and non-kin was mobilised and in all probability "exploited" to prepare a commensal feast. Among other things, there was a short-term accumulation of food and goods to be consumed, exchanged, given, and/or destroyed at the feast. These commensal feasts often, if not always, provided arenas for competition among socalled "Triple A" personalities (aggrandisers, accumulators, acquisators) who manipulated these "competitive feasts" for personal gain. Such competitive feasts thus helped create and maintain social inequalities, and much of the interest in competitive feasting has been in looking at it as a mechanism for the emergence of social inequality (Arnold 1993; Hayden 1995).

\section{IDENTIFYING FEASTS AND FEASTING BEHA- VIOUR IN THE ARCHAEOLOGICAL RECORD}

Two major classes of data have been used to identify feasting from archaeological remains. The first is the artefacts used in food preparation, presentation, and consumption, along with the contexts of their production, use, and disposal (e.g. Dietler 1996). In pre-ceramic archaeological contexts, more generally those contexts that lack evidence of containers, evidence of food preparation and presentation is limited to site furniture (features) for storage and cooking. Even so, the identification of these practices from pits, postholes, and hearths/ovens is still quite problematic. As such, the artefacts and features used to manipulate food can rarely be used in studies of the Palaeolithic and Mesolithic, although they are an 
extremely valuable source of information for studying food from later periods. Other indirect evidence of celebratory and mutual-aid feast might come from "aggregation sites", identified from variables such as site size and location (Butzer 1982) and/or artefact diversity (Conkey 1980; 1991). The second major class of data is the food itself. I focus on these data in my analysis of feasting during the Mesolithic at Pupićina Cave.

The few studies to date of archaeological signatures of feasting among hunter-gatherers have focussed on competitive feasts at which people "fought with food". Hayden (1996.137) suggests that competitive feasts might be recognised archaeologically on the basis of the following 6 characteristics:

(1) abundant resource base capable of providing surpluses;

(2) special foods used for feasting;

(3) special vessels used for serving feast foods (could include carved wooden bowls and gourds);

(4) the use of prestige items into which feast foods could be converted;

5 the occurrence of special grounds or structures at which feasting events could be held;

6 the occurrence of Triple A individuals having more wealth and influence than others in the community.

While there has been some interest in identifying competitive feasts and understanding the commensal politics that accompanied them (Dietler 1996), almost no attention has been given to celebratory and mutual-aid feasts. The focus on competitive feasts is understandable since the scale and regularity of such practices should make them more prominent in the archaeological record than celebratory and mutual-aid feasts. Another reason for the growing interest in competitive feasts is that they play a key rôle in some models of the emergence of social inequality (e.g. Hayden 1995).

The scale at which different foods were procured and consumed at relatively short-term events (duration of days to weeks) is one important distinction between feasts and every-day food consumption. The amount and density of food waste and/or its state of preservation/fragmentation should relate to the organisation and scale of food preparation and consumption. Although food storage is not necessary for competitive feasts, as shown by the Calusa of Florida, storage aids the accumulation of a surplus needed to underwrite feasts of any kind (Hayden 1996). Soffer (1989) and Rowley-Conwy \& Zvelebil
(1989) have reviewed evidence of the storage in the European Upper Palaeolithic and Mesolithic. As discussed briefly above with respect to food preparation and presentation, evidence of underground and above ground storage from the Palaeolithic/Mesolithic is for the most part fragmentary. Nevertheless, dried meat may have buffered subsistence risk and provided for feasts in addition to constituting a major form of wealth, along with buckskin during the Upper Palaeolithic (Hayden 1981). The production of both dried storable meat and buckskin would have required much labour. Thus, evidence of a feast might come from "copius food leftovers and much greater wastage than usual ... for example animal bones often are not completely broken up for marrow, and may not even be completely disarticulated, ... [since] feasting refuse tends to occur in considerable quantities in single deposits" (Hayden 1996. 138). Other than Hayden's suggestions about the value of dried meat and the ways in which carcass disarticulation and bone breakage might indicate unusual food waste, there have been relatively few attempts to identify feasting from food remains, regardless of whether those feasts were competitive, celebratory, or for mutual aid. The case study that follows is used to develop techniques for the identification of feasting from food remains as well as to explore the visibility of non-competitive feasting among prehistoric hunter-gatherers.

In summary, common characteristics of a feast include the scale and context of consumption. With a feast one expects the participation of consumers beyond the usual (local?) social group, including a range of relatives, visitors, and the like. Feasts often include a larger consumptive group, and in particular the consumption of a large amount of food in a relatively short period of time. There should thus be a larger scale of consumption than during regular meals. With a larger scale of consumption, one might expect economies of scale in the processing of food (resulting from much food being processed and consumed at once) and evidence of the provisioning of food. There might also be greater waste owing to limitations on the amount that people could eat. Also, there might be greater selectivity for particular food items. There might also be a greater representation of exotic items and unusual foods, both for diversity but more importantly to demonstrate the ability to mobilise resources from a wide range of areas, through trading links, or through the work effort of a large support group. Some of these practices use food to promote position and create prestige. 


\section{FEASTING AT PUPIĆINA CAVE}

\section{Pleistocene-Holocene Transition at Pupićina Cave}

Our topic requires high-resolution contextual data on food remains. The Pupićina Cave Project has been producing results that meet these stringent criteria of resolution and context. The Pupicina Cave Project is investigating prehistoric food management and mobility strategies within their palaeoenvironmental contexts in the northern Adriatic Basin, with particular reference to the northeastern portion of the Istrian Peninsula1. The overall goals of the project have already been summarised in a number of other places (Miracle 1997; 2001; Miracle et al. 2000; Miracle \& Forenbaher 2000), and the interested reader is referred to these publications for details of site location, size, excavation strategy, and other basic information.

The focus of the current study is on temporal changes in faunal assemblages excavated in 1995-1996 at Pupićina Cave. Pupićina is a large ( $25 \mathrm{~m}$ wide at the entrance and $30 \mathrm{~m}$ deep), south-east-facing cave located in a narrow, limestone canyon at an elevation of 220 metres above sea level. The detailed analyses presented below are based on $3.8 \mathrm{~m}^{3}$ of sediment excavated over an area of $6.5 \mathrm{~m}^{2}$ in 1995-96 (Fig. 1)2.

The lowest levels $(36,36 \mathrm{~A}-\mathrm{C}, 37,38)$ are massive, yellow-brown, silty-clays with very few clasts (Fig. 1). These levels were devoid of finds other than small, terrestrial gastropods. Radiocarbon dates from overlying levels confirm a late glacial age (Fig. 2). Relatively thin lenses $(2-10 \mathrm{~cm}$ thick) of animal bones, lithic artefacts, and charcoal mark two "cultural" levels $(35,32)$, the latter of which is associated with a hearth (Level 33). The matrix is still a silty-clay. Between these lenses the silty-clays are virtually "clean" of clasts other than small land snails. The most reliable absolute date on the middle cultural layer is $10150 \pm 60 \mathrm{bp}$ (Beta-131626), an AMS ${ }^{14} \mathrm{C}$ date on pine charcoal from hearth Level 33 (Tab. 1, Fig. 2)3. This date suggests deposition of these silty-clays at the very end of the Younger Dryas, and takes precedence over the date of $10610 \pm 200 \mathrm{bp}$ (Z-2574) on combined charcoal from Levels 31-34. The date $10020 \pm 180$ bp (Z-2631) on combined

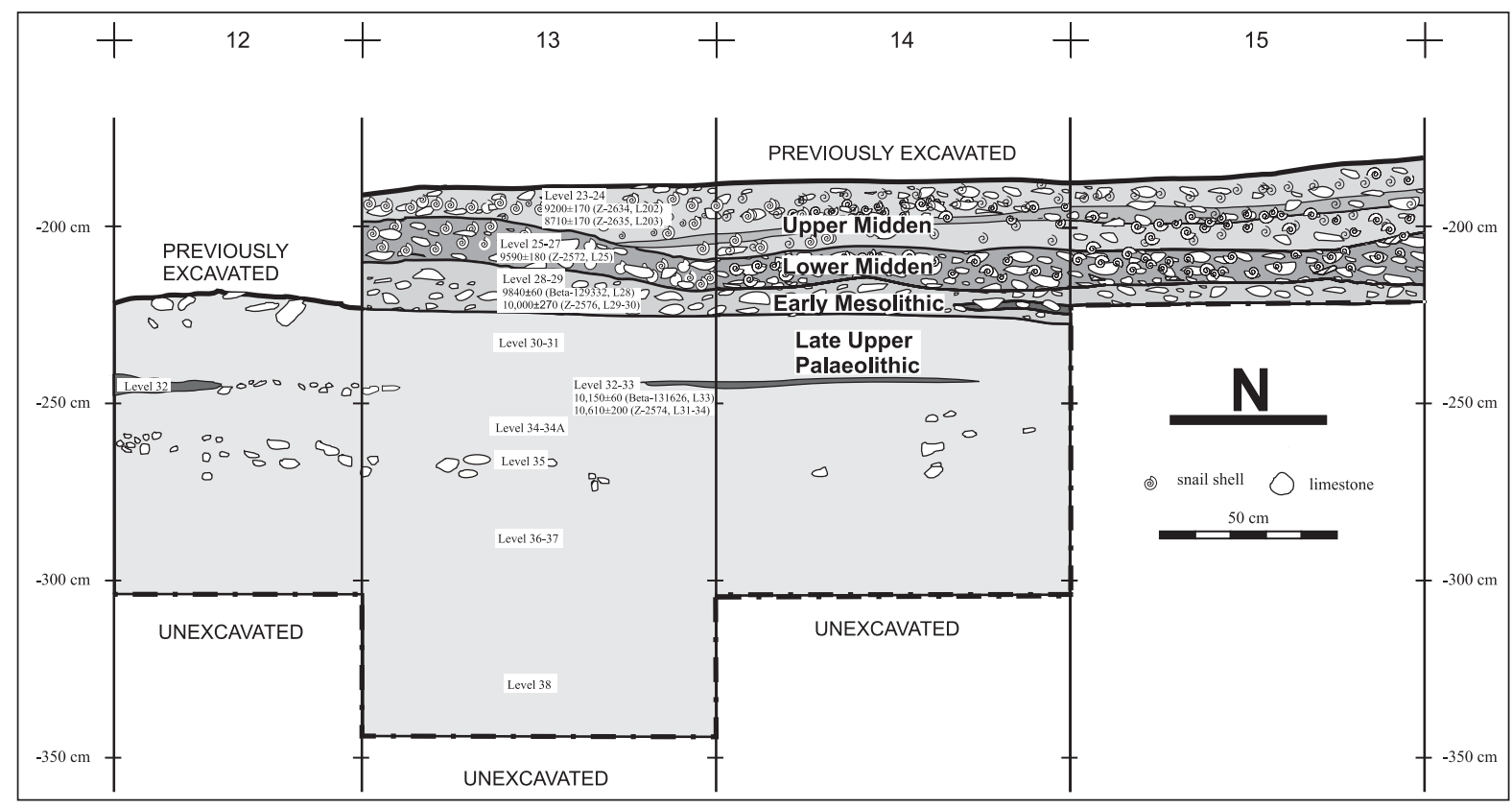

Fig. 1. Profile along N/O line in Pupićina Cave, showing Late Upper Palaeolithic and Mesolithic horizons, excavated levels, and ${ }^{14} \mathrm{C}$ dates.

1 The Pupićina Cave Project is a collaboration involving the following institutions: Cambridge University (Department of Archaeology), Zagreb University (Department of Archaeology), Archaeological Museum of Istria, and Croatian Academy of Sciences and Arts (Institute for Quaternary Geology and Palaeontology).

2 Excavation levels followed the natural stratigraphy, with units thicker than $10 \mathrm{~cm}$ subdivided using artificial spits. All sediments were dry-sieved using a 6-mm mesh in 1995 and a 3-mm mesh in 1996; a flotation sample (volume of 4 litres in 1995, 8 litres in 1996) was systematically taken from each square $\left(1 \mathrm{~m}^{2}\right)$ excavated in a level.

3 All dates were calibrated using 0xCal 3.3.0.2. 
Feast or famine? Epipalaeolithic subsistence in the northern Adriatic basin

\begin{tabular}{|c|c|c|c|c|}
\hline Phase & Excavation levels & ${ }^{14} \mathrm{C}$ Dates (lab, level) & $\begin{array}{l}\text { Calendar Age } \\
\text { BC (at } 1 \sigma \text { ) }\end{array}$ & $\begin{array}{l}\text { Excavated } \\
\text { volume }\left(\mathrm{m}^{3}\right)\end{array}$ \\
\hline $\begin{array}{l}\text { Upper Midden } \\
\text { (Mesolithic) }\end{array}$ & $24,202,202+203,203$ & $\begin{array}{l}9200 \pm 170(Z-2634, \text { L 202) } \\
8710 \pm 170(Z-2635, \text { L 203) }\end{array}$ & $\begin{array}{l}8690-8240 \\
8200-7550\end{array}$ & 0.764 \\
\hline $\begin{array}{l}\text { Upper Silts } \\
\text { (Mesolithic) }\end{array}$ & 204,205 & & & 0.175 \\
\hline $\begin{array}{l}\text { Lower Midden } \\
\text { (Mesolithic) }\end{array}$ & $25,26,27,203 A, 206$ & $\begin{array}{l}9590 \pm 180(Z-2572, \text { L 25) } \\
8770 \pm 310(Z-2578, \text { L 27) }\end{array}$ & $9220-8740$ & 0.553 \\
\hline $\begin{array}{l}\text { Early } \\
\text { Mesolithic }\end{array}$ & $28,29,207,208$ & $\begin{array}{r}9840 \pm 60 \text { (Beta-129332, L 28) } \\
10000 \pm 270(Z-2576, \text { L 29-30) } \\
11160 \pm 270(Z-2636, L \text { L 207) }\end{array}$ & $\begin{array}{l}9310-9225 \\
10200-9200 \\
11500-10950\end{array}$ & 0.387 \\
\hline $\begin{array}{l}\text { Late Upper } \\
\text { Palaeolithic }\end{array}$ & $\begin{array}{l}30,30+31,31,32,32+34, \\
33,34,34 \mathrm{~A}, 35,36,36 \mathrm{~A}, \\
36 \mathrm{~B}, 36 \mathrm{C}, 37,38\end{array}$ & $\begin{array}{l}10150 \pm 60(\text { Beta-131626, L 33) } \\
10610 \pm 200(Z-2574, \text { L 31-34) } \\
10020 \pm 180(Z-2631, \text { L 35) }\end{array}$ & $\begin{array}{l}10050-9450 \\
11000-10200 \\
10150-9300\end{array}$ & 1.802 \\
\hline
\end{tabular}

Tab. 1. Stratigraphic phases, absolute dates, and volume of sediment excavated at Pupicina Cave in 1995-96. Dates in bold are AMS determinations. Dates in italics are rejected (see text).

charcoal from Level 35 completely overlaps with the overlying date on Level 33 when both dates are calibrated. The similarity of these dates is probably owing to the effects of the radiocarbon plateau associated with the Younger Dryas as well as what appears to have been relatively rapid sedimentation at the site at this time. These three radiocarbon dates are consistent in dating what appear to have been very brief and ephemeral occupations at the site to the very end of the Pleistocene.

Above the "clean" silty-clays of Level 30, the frequency of limestone debris and organic material (wood charcoal and ash) in the silty-clay matrix increases dramatically; sediment colour also changes to grey-brown. The date of $10000 \pm 270 \mathrm{bp}(\mathrm{Z}-2576)$ on Levels 29-30 suggests that this shift in depositional regime marks the Pleistocene-Holocene boundary at Pupićina (Tab. 1) ${ }^{4}$. An early Holocene date of deposition is confirmed by an AMS ${ }^{14} \mathrm{C}$ date of $9840 \pm 60 \mathrm{bp}$ (Beta-129332) on pine charcoal. The date of $11160 \pm 270 \mathrm{bp}$ (Z-2636) on combined charcoal from Level 207 is rejected as too old. A small hearth (Level 208) was preserved in the surface of Level 207. The cave appears to have been occupied more frequently during the initial Holocene than during the late Pleistocene, although the intensity of occupation was not great enough to obliterate features like hearths.

Moving into the overlying levels, the sedimentary matrix becomes much ashier in the areas of the "midden". This "midden" was identified on the basis of the extremely high density of finds, especially ani- mal bones and large land snail shells, as well as wood charcoal, frequent limestone clasts, and what appear to be fire-cracked rocks. Two major components of the midden were identified, a "lower midden" that covered the entire area and contained a relatively high density of animal bones, and an "upper midden" that contained a relatively high density of Helix snail shells. These broad horizons contained multiple, discrete episodes of ash dumping and hearth cleaning that have created a complex horizontal as well as vertical stratigraphy; it was impossible to identify most of these episodes in excavation and profile. While a series of radiocarbon dates firmly date this midden to between about

Pupićina Cave: Absolute Dates

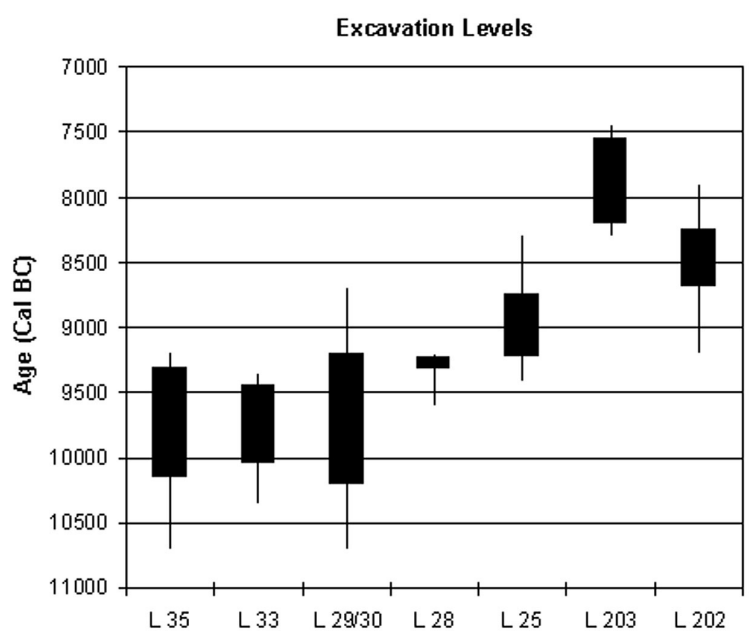

Fig. 2. Calibrated radiocarbon dates from late gla cial and early postglacial excavation levels at Pupićina Cave.

4 Most of the wood charcoal from level 30 came from the uppermost part of the level, and is most likely associated with a hearth (feature 1) and overlying cultural layer (level 29). 
8700-9600 bp (Fig. 2), several reversals indicate the complex and potentially mixed nature of these sediments. The "upper silts" contained a silty-clay matrix with some limestone clasts, yet little ash. They overlay the "lower midden". They appear to have been deposited at roughly the same time as the "upper midden". Although still undated, the "upper silts" are treated as temporally equivalent and spatially distinct to the ash lenses of the "upper midden". The uppermost Mesolithic level, which was capped by a hard-packed crust, was treated as a potentially disturbed level and excavated as an arbitrary ca. $5-\mathrm{cm}$ spit. This uppermost "Mesolithic surface" appears to have been a trampled surface, but will not be discussed further.

The correspondence of different excavation levels to the phases described above is presented in Table 1. The archaeological record from Pupićina Cave will be analysed using these broad phases, in part owing to the small sample sizes of many of the excavated levels. Although this gives a somewhat homogenised view of practices at any point in time, these phases capture the general changes in depositional regimes over time as well as giving a hint of some of the spatial contrasts between the "upper midden" and "upper silts".

\section{Mammal assemblage composition at Pupićina Cave}

The main taxa throughout the Late Upper Palaeolithic-Mesolithic sequence are red deer, roe deer, and wild boar (Tab. 2). Red deer varies in relative frequency from $23.9-51.7 \%$, while roe deer fluctuates between 10.0-15.7\%; neither taxa shows a temporal trend. Wild boar, in contrast, decreases from $18.6 \%$ during the LUP to $6.7 \%$ in the Upper Midden. Species richness increases from 7 taxa in the Late Upper Palaeolithic to 16 taxa in the Upper Midden. Taxonomic diversity increases significantly over time, with a major inflection between the Early Mesolithic and Lower Midden. The Total NISP identified in each phase also increases significantly over time, from NISP $=274$ in the Late Upper Palaeolithic to NISP= 1966 in the Upper Midden (Tab. 2). Thus, the change in taxonomic diversity closely correlates with an increase in Total NISP. Although changing species diversity is strongly conditioned by sample size, it is important to note that much of this increase in taxonomic diversity is achieved through the addition of relatively small-sized carnivores (e.g. marten, wild cat, badger, fox), hare, beaver, and hedgehog (Tab. 2). Cut marks indicate that at least some of these species were procured for skins and/or meat. Measured as a percent of Total NISP, small game doubles in frequency between the Early Mesolithic to Lower Midden (from 2.1\% to 5.3\%), and then doubles again to $9.6 \%$ in the Upper Midden. Although the Upper Silts have the smallest Total NISP, they have the highest frequency of small game at $17.4 \%$. This increase in the frequency of small game appears to reflect more than just changing assemblage size. This diversification of resource use is consistent with models of subsistence intensification owing to local factors of duration of occupation (Miracle 1997) and/or regional changes in ecological abundance and variability (Miracle 1996; Miracle \& O'Brien 1998), although it would be overstating the case to call this increase in small game frequency evidence of "famine".

\section{Land Snail Taphonomy and Consumption}

Land snails are ubiquitous in the Late Upper Palaeolithic and Mesolithic deposits at Pupićina Cave (Mi-

\begin{tabular}{|c|c|c|c|c|c|}
\hline Species & $\begin{array}{l}\text { Late Upper } \\
\text { Palaeolithic }\end{array}$ & \begin{tabular}{|c} 
Early \\
Mesolithic
\end{tabular} & $\begin{array}{l}\text { Lower } \\
\text { Midden }\end{array}$ & Upper Silts & Upper Midden \\
\hline \% Red deer & 37.1 & 36.4 & 51.7 & 23.9 & 29.5 \\
\hline$\%$ Roe deer & 15.7 & 12.0 & 11.5 & 10.0 & 13.3 \\
\hline$\%$ Wild boar & 18.6 & 22.8 & 14.2 & 9.0 & 6.7 \\
\hline$\%$ Small ungulate & 10.0 & 9.5 & 5.2 & 8.0 & 12.3 \\
\hline$\%$ Medium ungulate & 14.3 & 15.3 & 11.2 & 29.9 & 21.6 \\
\hline \% Small game 1 & 2.6 & 2.1 & 5.3 & 17.4 & 9.6 \\
\hline$\%$ Other & 1.7 & 2.0 & 0.9 & 2.0 & 7.0 \\
\hline Total NISP & 274 & 517 & 2493 & 201 & 1966 \\
\hline$\%$ Identifiable & 14.9 & 18.3 & 25.1 & 27.9 & 39.1 \\
\hline N Taxa & 7 & 7 & 13 & 9 & 16 \\
\hline $\mathrm{N}$ shaft fragments & 406 & 844 & 1855 & 231 & 1251 \\
\hline $\begin{array}{l}\mathrm{N} \text { articular ends \& } \\
\text { cancellous bone }\end{array}$ & 157 & 242 & 1632 & 86 & 672 \\
\hline Total faunal remains & 1845 & 2824 & 9916 & 720 & 5029 \\
\hline
\end{tabular}

Tab. 2. Relative frequency of major mammal taxa by stratigraphic phase at Pupicina Cave. 
racle 1997). Their taphonomy is usually complex since many species live in or near karstic caves, and a number of small carnivores (hedgehog, fox, mole etc.) eat snails and could collect their shells in caves and rockshelters. Stiner (1994; 1999) has remarked on several modifications of snail shells that point to non-human accumulators, in particular the presence of small punctures on otherwise undamaged shells. She has also remarked on the small size of many of the land snails from the Italian sites she has analysed.

The Pupićina land snail assemblage is divided into two components. The first includes relatively smallsized species, many of which are found in the entrance to Pupicina Cave today. The shells of these small land snails are mostly complete and preliminary analysis suggests that burning is very rare. These small land snails are most common during the LUP phase at Pupićina Cave. Their geometric density drops by a factor of 7 from the LUP $\left(116 \mathrm{MNI} / \mathrm{m}^{3}\right)$ to the Early Mesolithic $\left(16 \mathrm{MNI} / \mathrm{m}^{3}\right)$ and later levels (Tab. 3, Fig. 3). Interestingly, the density of these inedible land snails also increases in the Upper Silts relative to other phases of the Mesolithic. These small land snails are most frequent at the site when evidence of human occupation is sparsest. 5 Although a detailed taphonomic study of these snails remains to be done, the contextual evidence convincingly argues for non-human agents of accumulation and modification. We agree with Stiner (1994; 1999) that this component of the mollusc assemblage most likely reflects the activities of non-human accumulators.

The second component of the Pupićina land snail assemblage is the large-sized "edible" snail (Helix secernendra and Helix sp.) that is known from many late glacial to early postglacial contexts around the Mediterranean (Lubell et al. 1976; Miracle 1995). There is general agreement that Helix shells associated with fire-cracked rock and settlement debris in Capsian sites of North Africa reflect food waste ( $\mathrm{Lu}$ bell et al. 1976; Stiner 1999). Helix shells are present in very low quantities during the LUP at Pupićina. The geometric density of Helix shells increase by a degree of magnitude from the LUP $\left(9 \mathrm{MNI} / \mathrm{m}^{3}\right)$ to the Early Mesolithic $\left(88 \mathrm{MNI} / \mathrm{m}^{3}\right)$, with a similarly dramatic increase occurring between the Early Mesolithic and Lower Midden (to $1504 \mathrm{MNI} / \mathrm{m}^{3}$, Tab. 3, Fig. 3). The frequency of Helix remains high in the Upper Midden of the Mesolithic, although it is much lower $\left(325 \mathrm{MNI} / \mathrm{m}^{3}\right)$ in the Upper Silts. The frequency of Helix is the mirror image of the small land snails (Fig. 3). The high frequency of Helix is associated with ashy deposits that appear to have been dumped from hearths and roasting pits, a depositional context very similar to those at the open-air and clearly anthropogenic escargotières of the Capsian Culture of North Africa (Lubell et al. 1976). I suggest that the Helix land snails were prepared and eaten by people, although this interpretation remains preliminary until taphonomic studies are completed.

Land snails would have been a low-ranked resource when compared to the returns provided by ungulate hunts and any other gathered resource (Miracle 1995). The dramatic increase over time in land snail collecting

\section{Tab. 3. Frequency of main ungulates and molluscs by stratigraphic phase at Pupićina Cave.}

5 This relationship is even clearer if one compares "occupation" and "sterile" layers within the LUP phase. The frequency of small land snails varies inversely with other evidence of human use at this much finer stratigraphic resolution. 
thus provides some of the strongest indirect evidence of increasing resource stress during the Mesolithic at Pupićina - people broadened their diet to include lowly land snails in response to the depletion of higher-ranked resources in the vicinity of the site and/or within the wider region (Miracle 1997). These changes in early Holocene dietary composition may also reflect a longer period of occupation at the site, in addition to changes in group composition (particularly the presence of children) and/or individual strategies (Miracle 1997).

What I would like to suggest here is that the increase in Helix may also reflect a shift towards more feasting. Land snails can be collected in fairly large quantities. They can also be "stored" alive for a short time prior to consumption. Such "storage on the hoof" is practised today to improve the taste and reduce the toxicity of snails. The Romans "preseasoned" snails by feeding them milk, grain, and other delicacies prior to consumption (Renfrew 1996). One important aspect of a feast is being able to collect and store foodstuffs in preparation for the feast. Helix land snails may have been selected for collecting for those reasons. One potential drawback of collecting Helix is that it is relatively easy to overexploit a population, and it can take several years (or longer) for a population to bounce back from overpredation. At times when Helix was hyperabundant, people could have collected them in large quantities with relatively greater efficiency. People would have then had to lay off snails for a period of several years until local populations recovered.

\section{Marine Foods in the Hinterland}

Marine molluscs are present in the late glacial and early postglacial deposits at Pupićina. The mussel, Mytilus galloprovincialis, it the most common marine bivalve. These mussels must have been transported at least $20 \mathrm{~km}$ from the coast, and their presence at Pupićina provides tantalising evidence about the directionality and timing of contacts between coastal and inland areas (Miracle 1997). Most of the mussel shells are highly fragmented. I interpret these Mytilus shells as food waste. The geometric density of Mytilus increases ten-fold from the LUP to Early Mesolithic, rising from 3 to 34 hinges/ $\mathrm{m}^{3}$ (Tab. 3, Fig. $3)$. The frequency of Mytilus remains more or less constant in the Lower and Upper Middens of the Mesolithic, only to rise to 80 hinges $/ \mathrm{m}^{3}$ in the Upper Silts. The significance of this contrast between the midden deposits and the Upper Silts is still not clear, although it is interesting that the Upper Silts also had the highest frequency of small game.

The presence of Mytilus shells in the LUP phase at the very end of the Pleistocene suggests that water in the Kvarner Gulf and eastern coast of Istria was already sufficiently saline to support this species. This is not unexpected since comparison to global sea level curves suggests that the Kvarner Gulf may have flooded sometime between 11500 and 11000 Cal BC (Miracle 1995). Therefore, the increase in marine molluscs at Pupićina does not appear to be a simple function of proximity to the coast. The potential significance of these marine mussels for cooking techniques and "cuisine" is discussed elsewhere (Miracle 2001). Marine mussels are too rare to have been a significant food item, whether during good or bad times. It is difficult to interpret marine mussels as a "famine food" and their increasing frequency over time as indicative of subsistence stress. On the other hand, these seafoods would have been clearly "exotic" in comparison to the terrestrial game (mostly red deer, roe deer, and boar). In this hinterland context, marine mussels may have been "special foods" because of their origin from the sea. One might imagine taboos against the mixing of marine and terrestrial foods, and ingestion of mussels may have pyscho-socially transformed the consumer in various ways. Although the specific meanings associated with mussel consumption are not currently 


\begin{tabular}{|c|c|c|c|c|c|c|c|c|c|c|c|c|c|c|c|}
\hline \multirow{2}{*}{$\begin{array}{l}\text { Carcass } \\
\text { unit }\end{array}$} & \multicolumn{3}{|c|}{ | Late Upper Palaeo. } & \multicolumn{3}{|c|}{ Early Mesolithic } & \multicolumn{3}{|c|}{ Lower Midden } & \multicolumn{3}{|c|}{ Upper Silts } & \multicolumn{3}{|c|}{ Upper Midden } \\
\hline & NISP & $\%$ Bur & $\% \mathrm{CM}$ & NISP & $\%$ Burn & $\% \mathrm{CM}$ & NISP & $\%$ Burn & $\% \mathrm{CM}$ & NISP & $\%$ Burn & $\% \mathrm{CM}$ & NISP & $\%$ Burn & $\% \mathrm{CM}$ \\
\hline antler & 1 & 0.0 & 0.0 & 25 & 12.0 & 0.0 & 57 & 12.3 & 22.8 & 6 & 50.0 & 0.0 & 86 & 11.6 & 22.1 \\
\hline head & 10 & 0.0 & 0.0 & 39 & 7.7 & 0.0 & 275 & 4.4 & 1.1 & 16 & 0.0 & 0.0 & 97 & 5.2 & 7.2 \\
\hline upper teeth & 4 & 0.0 & 0.0 & 15 & 6.7 & 0.0 & 100 & 1.0 & 0.0 & 4 & 0.0 & 0.0 & 23 & 0.0 & 0.0 \\
\hline lower teeth & 5 & 0.0 & 0.0 & 10 & 0.0 & 0.0 & 77 & 2.6 & 0.0 & 1 & 0.0 & 0.0 & 38 & 0.0 & 0.0 \\
\hline neck & 8 & 0.0 & 0.0 & 6 & 33.3 & 0.0 & 69 & 4.3 & 17.4 & 4 & 0.0 & 0.0 & 47 & 2.1 & 17.0 \\
\hline back & 12 & 8.3 & 0.0 & 27 & 7.4 & 0.0 & 93 & 4.3 & 3.2 & 20 & 5.0 & 15.0 & 166 & 3.6 & 9.0 \\
\hline pelvis & 2 & 0.0 & 0.0 & 5 & 0.0 & 0.0 & 62 & 3.2 & 11.3 & 2 & 0.0 & 0.0 & 30 & 3.3 & 13.3 \\
\hline upper front & 13 & 0.0 & 15.4 & 20 & 5.0 & 0.0 & 148 & 5.4 & 10.8 & 9 & 0.0 & 11.1 & 84 & 14.3 & 9.5 \\
\hline lower front & 2 & 0.0 & 50.0 & 14 & 14.3 & 14.3 & 86 & 10.5 & 10.5 & 4 & 0.0 & 0.0 & 51 & 9.8 & 7.8 \\
\hline upper hind & 8 & 12.5 & 0.0 & 13 & 15.4 & 7.7 & 91 & 11.0 & 5.5 & 5 & 0.0 & 20.0 & 87 & 16.1 & 6.9 \\
\hline lower hind & 4 & 25.0 & 0.0 & 17 & 5.9 & 23.5 & 163 & 9.8 & 10.4 & 10 & 20.0 & 20.0 & 78 & 11.5 & 10.3 \\
\hline feet & 10 & 0.0 & 10.0 & 34 & 17.6 & 0.0 & 169 & 9.5 & 0.6 & 5 & 0.0 & 0.0 & 108 & 5.6 & 4.6 \\
\hline other & 10 & 10.0 & 0.0 & 42 & 11.9 & 2.4 & 179 & 9.5 & 3.9 & 22 & 0.0 & 9.1 & 168 & 11.9 & 1.8 \\
\hline Total NISP & 89 & 4.5 & 4.5 & 267 & 10.5 & 3.0 & 1569 & 6.8 & 5.9 & 108 & 5.6 & 8.3 & 1063 & 8.4 & 8.2 \\
\hline
\end{tabular}

Tab. 5. Red deer and medium ungulates: frequency of body parts and bone modification at Pupićina Cave.

For example, only a limited number of head bones were systematically recorded; only these bones were used to determine the correction factor. The main contrast in my usage to that of Gamble is in how I treat teeth. While a deer over its lifetime possesses 36 cheek teeth (18 upper and 18 lower), it would only rarely ever have all 36 in its mouth, and even then it is likely that no more than 24 (12 upper and 12 lower) would be in active use. This comes from the simple fact that deciduous teeth are exfoliated and lost with maturation, while permanent premolars are rarely visible (and hence not coded separately) in juvenile animals. Use of the correction factors makes the different carcass units equivalent to one another in their relative frequency in a deer skeleton. Corrected NISP for carcass units was then standardised to $100 \%$ by dividing values by the highest corrected NISP; calculation is identical to $\% \mathrm{MNI}$ and \%MAU used by other workers with the exception that corrected NISP is the basis for quantification7. Although NISP counts are presented for upper teeth, lower teeth, and back, these carcass units have not been corrected and included in further comparisons. Teeth are excluded since they are much denser than bone. Elements of the back are excluded since they are often underrepresented relative to other elements of the skeleton. The MGUI (Binford 1978) and volume density (Lyman 1984;

\begin{tabular}{|c|c|c|c|c|c|c|c|c|c|c|c|c|c|c|c|}
\hline \multirow{2}{*}{$\begin{array}{l}\text { Carcass } \\
\text { unit }\end{array}$} & \multirow{2}{*}{\multicolumn{3}{|c|}{$\begin{array}{l}\text { Late Upper Palaeo. } \\
\text { NISP \% Burn \% CM }\end{array}$}} & \multicolumn{3}{|c|}{ Early Mesolithic } & \multicolumn{3}{|c|}{ Lower Midden } & \multicolumn{3}{|c|}{ Upper Silts } & \multicolumn{3}{|c|}{ Upper Midden } \\
\hline & & & & NISP & $\%$ Burn & $\% \mathbf{C M}$ & NISP & $\%$ Burn & $\% \mathrm{CM}$ & NISP & $\%$ Burn & $\% \mathrm{CM}$ & NISP & $\%$ Burn & $\% \mathrm{CM}$ \\
\hline antler & 0 & & & 0 & & & 6 & 0.0 & 0.0 & & & & 27 & 33.3 & 0.0 \\
\hline head & 12 & 25.0 & 8.3 & 18 & 5.6 & 0 & 62 & 1.6 & 3.2 & 5 & 0.0 & 0.0 & 97 & 5.2 & 7.2 \\
\hline upper teeth & 7 & 0.0 & 14.3 & 5 & 0.0 & 0 & 30 & 0.0 & 0.0 & 1 & 0.0 & 0.0 & 23 & 0.0 & 0.0 \\
\hline lower teeth & 6 & 50.0 & 0 & 0 & & & 35 & 0.0 & 0.0 & & & & 38 & 0.0 & 0.0 \\
\hline neck & 5 & 20.0 & 0 & 2 & 0.0 & 0 & 16 & 0.0 & 0.0 & 3 & 0.0 & 0.0 & 47 & 2.1 & 17.0 \\
\hline back & 12 & 8.3 & 0 & 14 & 0.0 & 0 & 34 & 2.9 & 5.9 & 5 & 0.0 & 0.0 & 166 & 3.6 & 9.0 \\
\hline pelvis & 1 & 0.0 & 0 & 3 & 0.0 & 0 & 14 & 0.0 & 0.0 & 1 & 0.0 & 0.0 & 30 & 3.3 & 13.3 \\
\hline upper front & 5 & 20.0 & 40 & 16 & 12.5 & 6.3 & 45 & 4.4 & 2.2 & 4 & 0.0 & 0.0 & 84 & 14.3 & 9.5 \\
\hline lower front & 6 & 0.0 & 0 & 6 & 0.0 & 0 & 22 & 9.1 & 9.1 & 2 & 0.0 & 0.0 & 51 & 9.8 & 7.8 \\
\hline upper hind & 8 & 12.5 & 0 & 9 & 11.1 & 11.1 & 41 & 2.4 & 2.4 & 5 & 0.0 & 40.0 & 87 & 16.1 & 6.9 \\
\hline lower hind & 4 & 25.0 & 0 & 11 & 27.3 & 9.1 & 37 & 5.4 & 8.1 & 7 & 0.0 & 14.3 & 78 & 11.5 & 10.3 \\
\hline feet & 1 & 0.0 & 0 & 8 & 12.5 & 12.5 & 24 & 16.7 & 8.3 & 1 & 0.0 & 0.0 & 108 & 5.6 & 4.6 \\
\hline other & 15 & 0.0 & 0 & 19 & 15.8 & 0 & 51 & 3.9 & 2.0 & 2 & 0.0 & 0.0 & 168 & 11.9 & 1.8 \\
\hline Total NISP & 82 & 13.4 & 4.9 & 111 & 9.9 & 3.6 & 417 & 3.6 & 3.4 & 36 & 0.0 & 8.3 & 1004 & 8.8 & 6.8 \\
\hline
\end{tabular}

Tab. 6. Roe deer and small ungulates: frequency of body parts and bone modification at Pupicina Cave.

7 NISP is used instead of MNE. The latter has not yet been calculated because analyses are still ongoing. 
1994) are used as predictive models of carcass unit selection. Mean MGUI and Density were calculated by averaging values for the different elements included in each carcass unit8. Relationships between these variables and carcass unit frequency were assessed using scatter plots and nonparametric statistical measures of correlation (Spearman's r).

Mean MGUI and volume density are not significantly correlated (Spearman's $r=0.02, p=0.955,6$ degrees of freedom). Carcass unit frequency is not significantly correlated with volume density in any of the phases for either red deer/medium ungulates or roe deer/small ungulates; Spearman's $r$ ranges from -0.40 to 0.14 . Density-mediated destruction of bones has not significantly patterned body part frequency in these assemblages.

In contrast to volume density, there are strong positive correlations between food utility, as measured by the mean MGUI, and carcass unit frequency. Looking first at red deer and medium ungulates (Figs. 4-5), mean MGUI and carcass unit frequency are po-

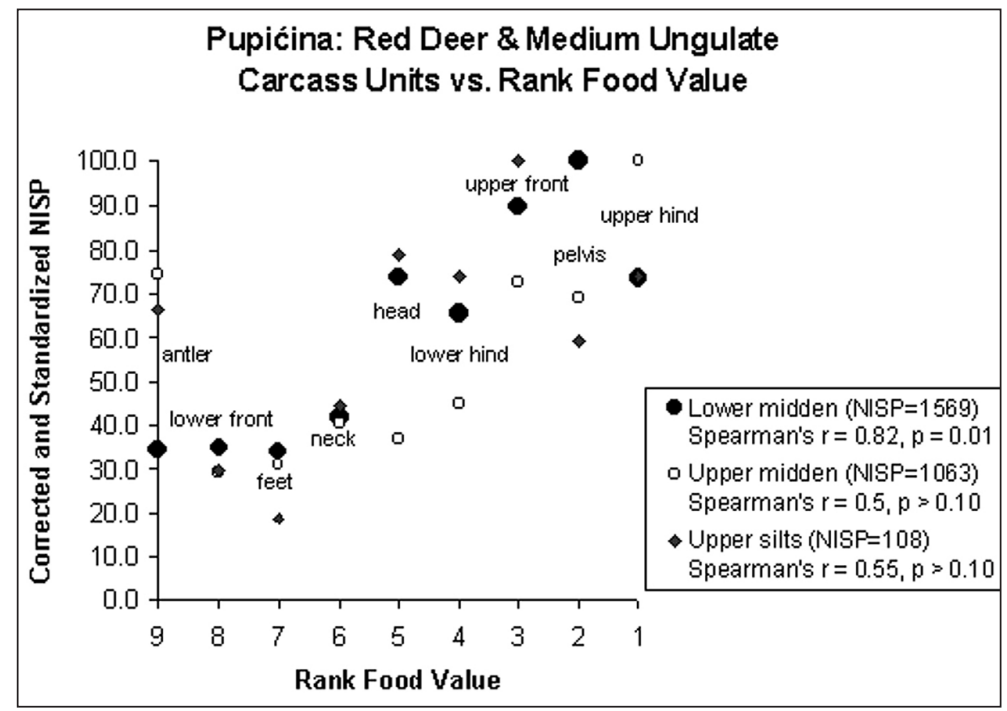

Fig. 5. Carcass unit frequency vs. rank food utility for red deer and medium ungulates from Lower Midden and Upper Midden Mesolithic phases at Pupicina Cave.

\section{Pupićina: Red Deer \& Medium Ungulate} Carcass Units vs. Rank Food Value

Fig. 4. Carcass unit frequency vs. rank food utility for red deer and medium ungulates from LUP and Early Mesolithic phases at Pupićina Cave.

sitively correlated in the LUP (Spearman's $r=0.77$, $p=0.03,7$ d.f.), but not in the Early Mesolithic (Spearman's $r=0.20)$. If one removes antler from the analysis, then there is a strong positive correlation for the Early Mesolithic (Spearman's $r=0.68$, $p=0.06,6$ d.f.), while that for the LUP becomes weaker (Spearman's $r=0.67, p=0.07,6$ d.f.). In upper case the midden deposits of the Mesolithic correlations between food utility and carcass unit frequency are extremely high and positive in the Lower Midden (Spearman's $r=0.82, p=0.01,7$ d.f.) and also in the Upper Midden if one removes antler from the analysis (Spearman's $r=95, p<0.001,6$ d.f.). There is not a clear relationship between carcass unit frequency and food value in the Upper Silts, regardless of whether one includes antler in the analysis. There was clearly a very strong selection for the meatiest parts of the red deer (and medium ungulate) carcass during the midden phases of the Mesolithic (Fig. 5). All parts of the carcass were being brought to Pupićina during the different phases of occupation. There was a shift over time, however, towards a selection for the meatiest carcass

8 The maximum volume density has been used for each element, which in the case of the limbs comes from the shaft. Limb shafts were identified to element and body size based on nutrient foramina and other diagnostic anatomical features. This use of volume density is appropriate since I am examining the relative frequency of different carcass parts rather than differential survivorship within individual bones. This assumes, of course, that limbs were initially transported and manipulated whole rather than in pieces, i.e. disarticulation was between bones rather than through them. 
parts so that there was a surplus of high utility elements relative to the rest of the carcass during the midden phases of the Mesolithic. Antler was also collected during the Early Mesolithic and Upper Midden phases, probably for use as a raw material for manufacturing antler tools. The interpretation I favour is of people provisioning Pupićina with the meaty upper limbs of red deer carcasses during the Mesolithic.

Turning to the roe deer and small ungulates, we again find significant correlations between food utility and carcass unit frequency (Figs. 6-7). Carcass unit frequency is not significantly correlated with food utility in the LUP (Spearman's $\mathrm{r}=0.65, \mathrm{p}=$ $0.08,7$ d.f.). In the Early Mesolithic through Upper Midden, however, food utility is significantly correlated with food utility, with rank correlation coefficients ranging from $r=0.82$ to $r=0.94$ (Figs. 6-7). The assemblage from the Upper Silts is not included owing to its small sample size. As with the red deer and medium ungulates, the shift from LUP to Mesolithic is not simply a matter of sample size - sample sizes in the LUP and Early Mesolithic are very similar. This suggests a deliberate provisioning of the site with the meatier elements of roe deer and small ungulates during the Mesolithic occupations of the site.

Further evidence of the differential provisioning of Pupićina with meaty carcass parts during the Midden

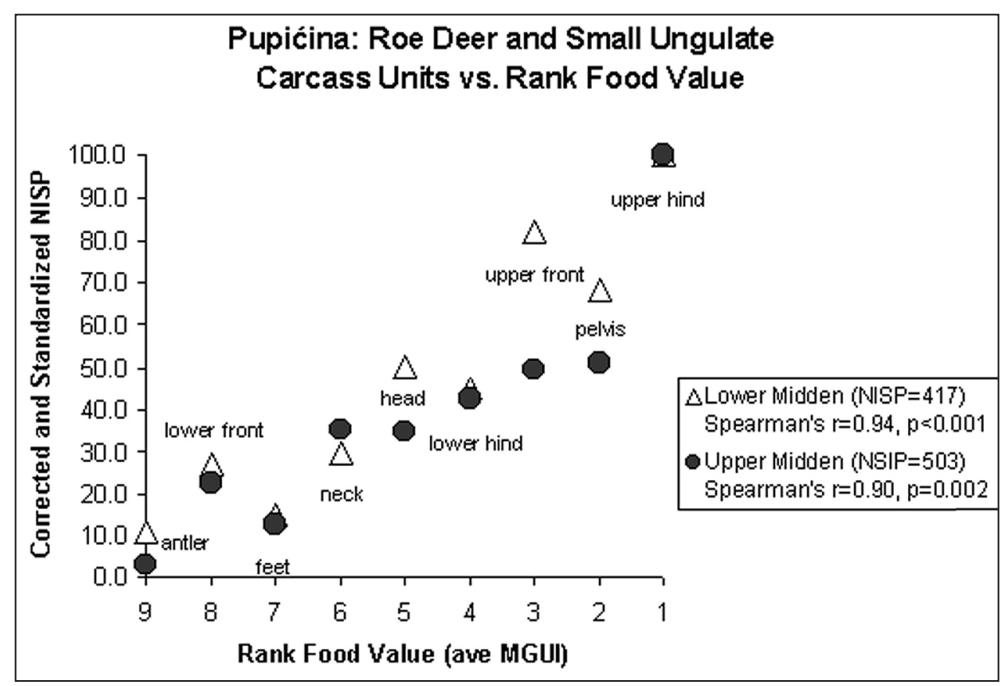

Fig. 7. Carcass unit frequency vs. rank food utility for roe deer and small ungulates from Lower Midden and Upper Midden Mesolithic phases at Pupićina Cave.
Pupićina: Roe Deer and Small Ungulate

Carcass Units vs. Rank Food Value

Fig. 6. Carcass unit frequency vs. rank food utility for roe deer and small ungulates from LUP and Early Mesolithic phases at Pupićina

phases of the Mesolithic comes from the differential representation of bones from the right versus left side of the animal. The only incidence of bias for a particular side in red deer and medium ungulates is in the upper front limb from the Lower Midden, with NISP $=45$ for left side and NISP $=87$ for right side $\left(\chi^{2}=13.4, p<0.001,1\right.$ d.f.). In the roe deer and small ungulates there appears to be a preferential selection for upper hind limbs in the Early Mesolithic (NISP $=4$ for left side compared to NISP $=0$ for right side, $\chi^{2}=4.0, p=0.045,1$ d.f.) and Lower Midden (NISP $=23$ for left side compared to NISP $=$ 12 for right side, $\chi^{2}=3.46, p=0.063,1$ d.f.), although the latter relationship is not statistically significant. It is quite interesting that evidence of a bias for a particular side of the body appears only in the meaty parts of the carcass as opposed to the rest of the carcass, and mostly comes from the Lower Midden. These data complement evidence of a selective transport of higher utility elements to the site during the Midden phases of occupation.

Evidence of further processing is more difficult to interpret. The frequency (\% of NISP) with which different carcass units are burned and cut is presented in Tables 5 and 6 . The interpretation of burning data is far from clear (Kent 1993) since burning may have little to do with food preparation and consumption, 
and may be postdepositional in origin (Stiner et al. 1995). Likewise, as numerous authors have noted, nicking bone dulls a sharp edge. Cut mark frequency and location are strongly conditioned by an animal's anatomy, including the location and attachment of major muscles and tendons, as well as in the ease with which bone can be avoided during skinning, carcass disarticulation, and defleshing. On the other hand, there is anecdotal evidence that cultural differences also contribute to distinctive butchery styles (Langenwalter 1980; Lyman 1987; Yellen 1977). With reference to the faunal remains from Pupicina, my question is what the burning and cut mark data might be revealing about the scale at which butchery and consumption was occurring. In particular, are there changes in burning and cut mark frequency that might be interpreted in terms of feasting?

Bones were coded as burned when they were at least partially charred dark brown to black in colour. The category of "burned bone" thus includes bones that have been charred and calcined; it excludes bones that may have been only lightly burned. Burning frequency in red deer and medium ungulates ranges from $4.5 \%$ to $10.5 \%$ of NISP (Tab. 5). The frequency of burning increases from the Late Upper Palaeolithic to Mesolithic phases, with the highest frequency of burning in the Early Mesolithic. There is even greater variability among phases in the distribution of burning within the skeleton. To give a better sense of bone burning relative to anatomy, burning frequency by carcass unit is represented on schematic drawings of a deer carcass (Figs. 8-11). These schematic drawings show that burning is not distributed at random on the different carcass parts. In fact, in most cases burning frequency is relatively similar among neighbouring carcass units (e.g. axial skeleton in Figures 10 and 11)9. Carcass units with similar burning frequencies are likely to have been burned together, whether as part of food preparation/discard or owing to postdepositional fires. From this perspective, a major difference in burning frequency between adjacent carcass units is important in that it suggests that burning occurred after disarticulation/dispersion of skeletal elements. In the LUP red deer/medium ungulates, the upper and lower hind limb are relatively more burned than the adjacent pelvis and feet (Fig. 8). Many carcass units were not burned at all, including some of the relatively meaty portions like upper fore limb and pelvis.
These parts may have been filleted and discarded at Pupićina with consumption occurring elsewhere. The sample size is admittedly small and results are preliminary, but the overall impression is that red deer and medium ungulate carcasses had already been disarticulated prior to burning. Much of this burning may have been incidental or resulted from the disposal of bone waste into fires following consumption. It will certainly be informative to study the spatial distribution of bone burning in these late glacial levels, particularly with respect to the placement of hearths. In the Early Mesolithic burning frequency is consistently higher on all carcass units compared to the LUP, although there is a similar pattern of discrepancies between adjacent carcass parts (Fig. 9). The relatively high frequency of burning on antler may be related to tool manufacture, while the sharp contrast in bone burning between the head and neck is good evidence that the head had been removed from the neck prior to burning. Red deer heads may have been processed/disposed in a different manner from the rest of the body. Perhaps they were roasted with hide and flesh still attached, or they may have been boiled/stewed. They may have been deposited away from fires due to respect to the animals. A more specific interpretation of the heads is not possible at this point in time, although the pattern is striking. The rest of the carcass shows consistent burning frequencies, excepting a discrepancy between the pelvis and upper hind limb. This pattern of burning may not be what one would expect if carcasses were roasted whole. We still lack adequate baselines for interpreting this kind of burning data. In the Lower Midden antler is more frequently burned than the head, and the upper hind limb is much more frequently burned than the pelvis and back (Fig. 10). As mentioned above, the high frequency of antler burning may be related to its use as a raw material for tool manufacture. The evidence of the upper hind leg suggests that it had already been disarticulated from the pelvis prior to burning. In general, I also note that the axial skeleton is uniformly burned to a slight degree, while limbs are more heavily burned. This may suggest that limbs were separated from the trunk prior to cooking. This certainly fits with other evidence of upper limbs being introduced to the site; these limbs may have been treated separately from other parts of the carcass, perhaps for preparation/cooking on a larger scale as part of a feast. Finally, in the Upper Midden

\footnotetext{
9 Treatment of feet on these drawings is somewhat problematic. It is very difficult to distinguish between phalanges of the fore and hind limb, particularly when complete phalanges are rare as at Pupićina. Thus, in presenting these data I have assumed the burning was equally distributed among fore and hind phalanges.
} 


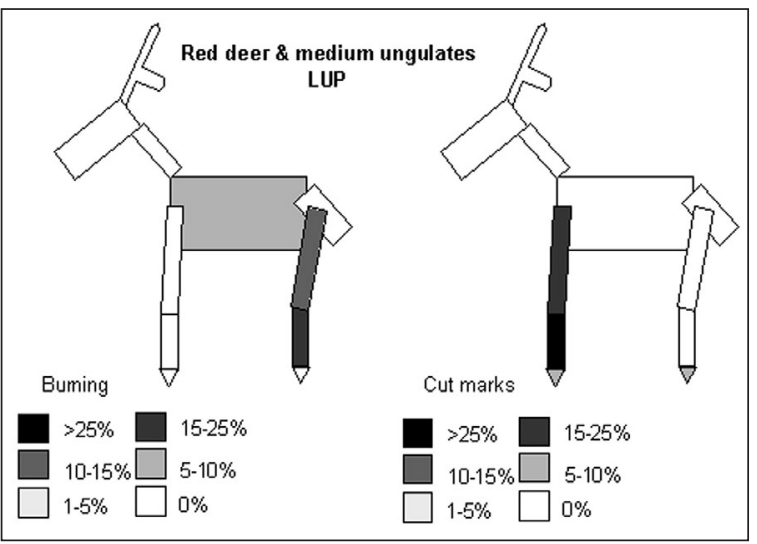

Fig. 8. Frequency of burning and cut marks (\% of NISP) on carcass parts of red deer and medium ungulates in the LUP phase at Pupićina Cave.

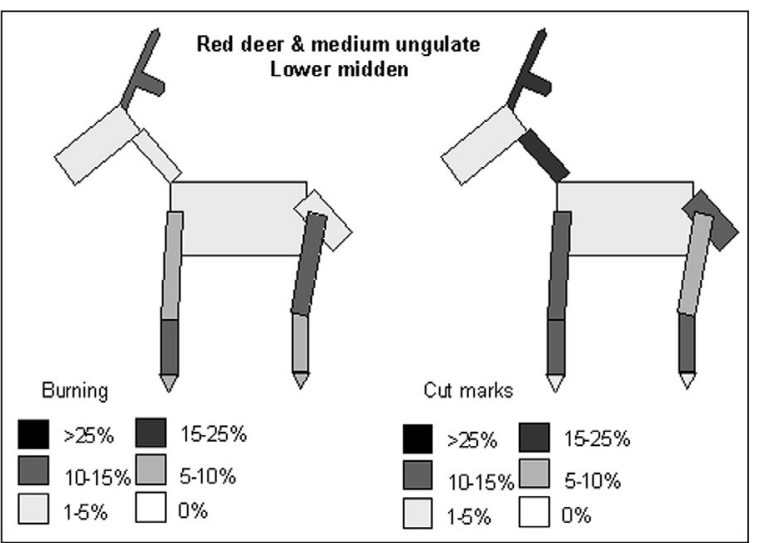

Fig. 10. Frequency of burning and cut marks (\% of NISP) on carcass parts of red deer and medium ungulates in the Lower Midden phase at Pupicina Cave.

antler is again much more frequently burned than the head, while now both the upper fore and hind limbs are much more frequently burned than the back and pelvis (Fig. 11). The contrast between the Upper Midden and Upper Silts is also evident in the much lower frequency of burning in the latter compared to the former context. My interpretation of these patterns is much as it was for the Lower Midden, with the exception that evidence for a differential treatment of limbs versus the trunk is even stronger. While keeping in mind the shortcomings that come from a lack of interpretative baselines, I suggest that this evidence is consistent with preparing and cooking red deer at a larger scale. This may be evidence of feasting.

Anatomical data on cut mark frequency is presented in the same way as the data on bone burning (Figs. $8-11)$. The overall frequency of cut marks ranges from $3.0-8.3 \%$ of NISP; in contrast to bone burning,

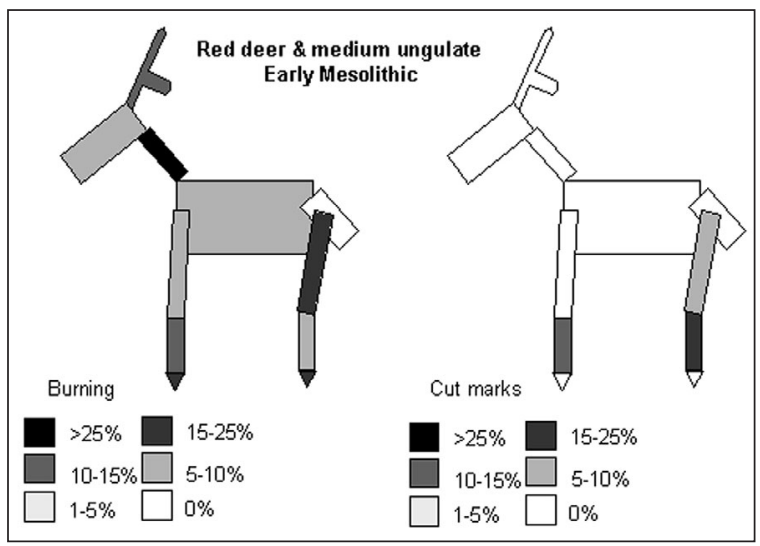

Fig. 9. Frequency of burning and cut marks (\% of NISP) on carcass parts of red deer and medium ungulates in the Early Mesolithic phase at Pupićina Cave.

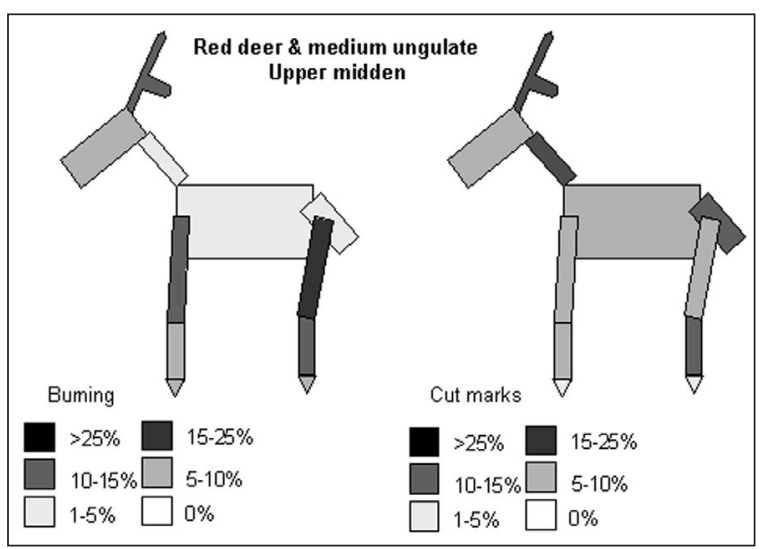

Fig. 11. Frequency of burning and cut marks (\% of NISP) on carcass parts of red deer and medium ungulates in the Upper Midden phase at Pupicina Cave.

cut mark frequency increases from the earliest to latest phases under consideration (Tab. 5). While we have some interpretative baselines for the position and form of cut marks on bones (e.g. Binford 1981; Noe-Nygaard 1989; Lyman 1994), little is known about the factors that affect the overall frequency of cut marks on bones. Intuitively, it seems likely that an increase in the range and kind of butchering practices will cause an increase in cut mark frequency. Likewise, the frequency of "mistakes" must increase with the overall intensity of skinning, disarticulation, and filleting. I suggest that the increase in cut mark frequency from the LUP to Upper Midden reflects both an increase in the range of butchery practices and a more intensive butchery of carcasses. The latter could have resulted from carcasses being divided into relatively smaller portions, perhaps related to the transport of already butchered parts to the site as well as a wider or more extensive sharing of meat at the site. Turning to the distribution of 
cut marks on red deer carcasses, cut marks are limited to the fore limb and feet during the LUP (Fig. 8) and to the hind limb and lower fore limb during the Early Mesolithic (Fig. 9). Cut marks are more widely distributed on carcasses in the Lower Midden (Fig. 10) and Upper Midden (Fig. 11). The relatively high frequency of cut marks on antler in the Lower Midden may be related to tool production. On the other hand, the relatively high frequency of cut marks on the neck and pelvis in both Lower and Upper Middens is probably related to dismemberment. Overall, red deer carcasses appear to have been more thoroughly dismembered and filleted during the Midden phases relative to the LUP and Early Mesolithic. The link between this pattern and consumption of food at a larger scale and feasting remains to be established, although this pattern is not incongruent with such an interpretation.

Roe deer and small ungulates show a similar degree of burning and cut marks as found on red deer and medium ungulates. Burning frequency ranges from $0.0-13.4 \%$ of NISP, while cut mark frequency ranges from 3.4-8.3\% of NISP (Tab. 6). There are not any clear stratigraphic trends in these data. The anatomical distribution of bone burning shows a pattern similar to that observed in red deer and medium ungulates. In the LUP and Early Mesolithic, adjacent carcass units show very different degrees of burning, suggesting burning after major disarticulation/dispersion, while burning is more evenly distributed among carcass units in the Lower and Upper Midden (Tab. 6). Cut marks are rare or missing from the neck and pelvis in contrast to red deer and medium ungulates; units of butchery may have included more carcass parts in roe deer than in the larger-sized red deer. Cut marks on feet in the Early Mesolithic and Lower Midden are probably from skinning; much of the initial carcass butchery and processing appears to have occurred at Pupićina. Cut marks are very localised, primarily on limbs, in the LUP and Early Mesolithic; they are more evenly distributed across the carcass in the Lower Midden and Upper Midden. Some of this contrast may be owing to the increase in sample size in the later phases; as with the red deer and medium ungulates, links between cut mark distribution and patterns of food consumption remain to be established.

The intensity of carcass processing may give another indication of feasting. A feast involves the consumption of relatively large quantities of food over a restricted period of time. This may lead to the generation of not only large amounts of food waste, but also the wasting of large amounts of food. The operationalisation of these observations in most archaeological contexts, however, is quite difficult. One indicator would be the deposition of incompletely butchered and processed carcasses among food waste. Anecdotal observations at Pupićina suggest that partially articulated limbs and vertebral columns are more frequent in the Midden phases than during the LUP. These partial articulations are mixed among the rest of the faunal remains in the deposits; nothing sets apart these remains as having come from "structured" deposition.

Another indication of wasting food might be a less intensive processing of carcasses for bone grease and marrow; this would also suggest that other sources of animal fat were available. The identification of processing intensity from faunal remains comes with other problems (see Miracle 1995), in particular the distinction between human food preparation/consumption practices and post-depositional fragmentation caused by a range of agents. The frequency of teeth relative to bony parts of heads gives one indication of post depositional fragmentation. Since teeth are much denser than bones, a relative increase in the former relative to the latter should indicate greater postdepositional destruction. Comparison of teeth to heads is also very useful since they are likely to move together (leaving out pierced teeth used as ornaments); therefore the relative frequency of teeth to heads should indicate in situ destruction rather than differential transport of heads relative to other parts of the carcass. Using data in Tables 5 and 6, we can see that the ratio of NISP teeth/NISP head varies from $0.32-0.90$ in red deer and medium ungulates, while in roe deer and small ungulates it ranges from 0.20-1.08. None of these assemblages are dominated by teeth in a fashion that one might expect if there had been extremely postdepositional fragmentation. Likewise, there are not any clear stratigraphic trends in these parameters. As noted in the previous discussion of food utility, there are not clear relationships between bone density and carcass unit frequency.

Another approach to postdepositional fragmentation is to examine the fragmentation of relatively small, dense bones without marrow (Marean 1991; Miracle 1995). These bones are unlikely to have been fractured by people in butchery or processing. Their completeness, coded from a minimum of $10 \%$ complete to a maximum of $100 \%$ complete (unbroken) should give a rough indicator of fragmentation by non-human agents. In particular this would be post- 
depositional fragmentation since there is little for a carnivore to gain from them, and carnivores tend to swallow them whole rather than gnawing them into pieces (Marean 1991). The completeness of carpals, tarsals (excepting calcaneus), sesamoids, accessory phalanxes and accessory metapodials is summarised by phase in Table 7 . Red deer and medium ungulates show an increase in mean completeness from $85 \%$ in the Early Mesolithic to $91.7 \%$ in the Upper Midden; the sample size $(\mathrm{N}=1)$ from the Late Upper Palaeolithic is too small for a comparison. The slight differences in completeness within the Mesolithic phases are not statistically significant (two-tailed ttests for samples with unequal variance). Roe deer and small ungulates show a slight decrease over time in mean completeness from $95.8 \%$ to $88.8 \%$ (excluding the single bone from the Upper Silts). Again differences are not statistically significant and sample sizes from the earlier phases are quite small. These data suggest that the effects of postdepositional fragmentation did not change dramatically over time. While postdepositional fragmentation has certainly had important effects on the faunal assemblages from Pupićina, alone it does not account for the stratigraphic changes that I will now discuss.

One crude yet effective measure of fragmentation is the percent of remains identifiable to species and/or skeletal element. Among other factors, the ease and possibility of identification of remains is a function of completeness; identifiability decreases as fragmentation increases. This "\%Identifiable" is calculated as the NISP/N faunal remains (Tab. 2). While this parameter has been shown in some contexts to be strongly dependent on sample size (Grayson 1984), graphic comparison of \%Identifiable vs. sample size (from individual excavation units) shows that there is no relationship between these variables (Fig. 12). The percentage of identifiable remains ranged from 14.9-39.1\% and showed a clear stratigraphic trend towards greater identifiability in the later phases. There is also a spatial distinction, with less fragmentation in the Upper Midden (39.1\%) than in the Upper Silts (27.9\%). Bone fragmentation decreased from the LUP to the Upper Midden.

Another measure of fragmentation is mean fragment weight (NISP/wt). In red deer and medium ungulates, the average weight per fragment increases slightly from $10.1-11.1 \mathrm{~g}$ from the LUP to the Upper Midden (Tab. 3). The roe deer and small ungulates show a similar trend, from 1.9 to $3.4 \mathrm{~g}$ from the LUP to the Upper Midden. As with identifiability, mean fragment weight of both small and mediumsized ungulates is less in the Upper Silts than the Upper Midden. As discussed above, a change in postdepositional fragmentation does not account for this trend in fragment weight. These trends coarsely indicate a temporal shift from more to less intensive bone fragmentation, and by inference carcass processing, from the Late Upper Palaeolithic to Upper Midden.

Zooarchaeologists often compare fragmentation rates among skeletal elements to study carcass processing in greater detail. Unbroken bones were clearly not used for marrow or grease. At Pupićina, almost all marrow-bearing bones have been broken, and many show clear evidence of impact scars indicating that they were cracked for marrow extraction. Only two out of 227 red deer and medium ungulate first and second phalanxes were unbroken, while all of the 49 roe deer and small ungulate first and second phalanxes were broken. There are not any temporal trends in these data. From these results one might conclude that people at Pupićina were constantly making maximal use of all potential food sources from a carcass, and hence were under dietary stress. On the other hand, the cracking of phalanxes for marrow may have been something done to pass the time while telling stories around the fire (Gamble 1997).

Instead of focussing on variation in fragmentation among elements, I will examine the differential preservation of different parts of individual elements. My point of departure is Binford's (1978) observations among the Nunamiut that the frequency of long bone shaft fragments to articular ends was indicative of the intensity with which bones were pro-

\begin{tabular}{|l|ccc|ccc|}
\hline & \multicolumn{3}{|c|}{$\begin{array}{c}\text { Red deer \& medium ungulates } \\
\text { Mean }\end{array}$} & \multicolumn{3}{c|}{ Roe deer \& small ungulates } \\
Phase & completeness & S.D. & N & completeness & SD & N \\
\hline Upper Midden & 90.5 & 21.0 & 44 & 88.8 & 16.4 & 12 \\
Upper Silts & 91.7 & 14.4 & 3 & 100.0 & N/A & 1 \\
Lower Midden & 89.2 & 25.1 & 97 & 82.1 & 28.0 & 12 \\
Early Mesolithic & 85.0 & 33.5 & 11 & 65.0 & 33.5 & 5 \\
Late Upper Palaeolithic & 10.0 & N/A & 1 & 95.8 & 10.2 & 6 \\
\hline
\end{tabular}

Tab. 7. Mean completeness (100 maximum) of carpals, tarsals, sesamoids, accessory phalanxes, and accessory metapodials in red deer \& medium ungulates and roe deer \& small ungulates at Pupićina Cave. 


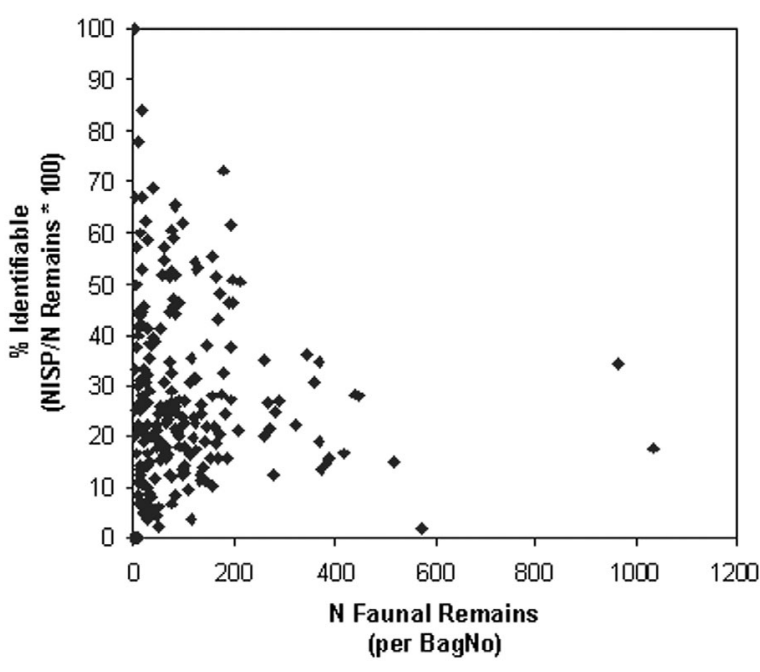

Fig. 12. \%Identifiable versus sample size by excavation lot (BagNo) at Pupićina Cave.

cessed for marrow, bone juice, and/or grease extraction. Enloe (1993) has further studied some of these ethnoarchaeological assemblages to develop criteria for the identification of marrow extraction. Rather than trying to use these data to identify specific practices, I simply note that one expects the ratio of shaft fragments to articular ends to increase as bones are more intensively processed, owing to the higher susceptibility of ends to destruction, their higher grease content relative to shafts, and the need to break up articular ends to help free grease. The frequencies of long bone shafts (including small splinters and chips not identifiable to body size) and long bone ends (including unidentifiable cancellous bone) $\mathbf{1 0}$ for different phases are presented in Table 2. The ratio of long bone shafts to articular ends calculated using data in Table 2 is relatively high in the LUP (2.59) and Early Mesolithic (3.49); it drops substantially in the Lower Midden (1.14), only to rise again slightly in the Upper Midden (1.86). The ratio of shafts to ends is much higher in the Upper Silts (2.68) than in the Upper Midden. These data suggest that long bones were more intensively processed, perhaps by crushing articular ends for bone juice and/or grease, during the LUP, Early Mesolithic, and Upper Silts relative to the later phases of the Midden. Not only did fragmentation decrease over time, but also the pattern of fragmentation shifted from the articular ends to the shafts of long bones. These preliminary interpretations suggest a shift in the importance being placed on the extraction of lipids from bones. An increase in the processing of bone grease over time would fit interpretations of increa- sing dietary stress (Miracle 1995). Bone grease may have also been produced in preparation for a feast; the consumption of large amounts of animal oil/fat was a key component of ethnographically documented feasts (e.g. Boas 1966; Codere 1950).

\section{DISCUSSION}

Several lines of evidence indicate an increase over time in the scale of animal food consumption at Pupićina Cave. These changes are manifest in the following ways:

- the range and kind of species collected, in particular an increasing emphasis on edible land snails and marine molluscs;

- the amount of food refuse deposited on site;

- the provisioning of the site with carcass parts high in food value;

- patterns of burning and cut marks indicating a more systematic and intensive use of entire carcasses at once;

- decreased bone fragmentation and less intensive use of carcasses in later phases.

Results from these different analyses are not uniformly strong, and some of the suggested links with feasting need further comparative study. Nonetheless, the redundancy of patterning in independent lines of evidence gives credibility to the suggestion that there was a shift in food consumption practices, with feasting more important in early postglacial than late glacial phases of site use. These new food consumption practices are accompanied at the site by other changes in material culture, namely the appearance of pierced tooth and shell ornaments and occasional human remains. These later data still await detailed analysis, but reinforce the interpretation put forward here that changes were qualitative as well as quantitative. The record of food consumption at Pupicina suggests that Dietler's (1996.102) pessimistic assessment of "our ability to detect feasts in the [Mesolithic] archaeological record" was premature.

The presence of feasting raises interesting possibilities about commensal politics and the basis of leadership and power in Mesolithic societies in the northern Adriatic basin. Dietler (1996) and Hayden (1996) have both suggested that commensal politics may have started to become important during the Meso-

10 Some of this cancellous bone may be from vertebral centra. Hence, ratios of shaft fragments/ends may be slightly depressed compared to the actual values. 
lithic in Europe. In particular, Hayden (1996.141142) has argued "on the basis of analogies with American Northwest Coast cultures ... that competitive feasting systems also were operating in the rich coastal and riverine environments of Mesolithic Europe". While Pupicina is not on the coast, it was clearly part of a settlement system that included the coast. Environmental richness is more difficult to evaluate, but the region seems to have supported diverse and probably abundant natural resources. At Pupićina the appearance of human remains in the midden intermixed with feasting refuse raises the possibility that the manipulation of human relics (including symbolic consumption of flesh?) were important components of feasts. A presencing of ancestors might be accompanied by group affirmation and social bonding, and would better fit Hayden's definition of a "celebratory feast" rather than a commensal or competitive feast. On the other hand, the involvement of ancestors may have served to highlight social distinctions among feast participants and could thus have contributed to commensal politics. With only preliminary results available, it would be unwise to push interpretations of the Pupićina data in a particular direction; results of analyses of other classes of data will shed further light about the structure and nature of feasts at the site.

Categorical contrasts like "feast-famine" can be useful analytical and rhetorical devices. As shown above, however, many of the temporal trends and patterns in the data fit interpretations of dietary stress as well as feasting. Scale is certainly an important issue. People could have periodically held feasts (shortterm events) during a period of declining resource availability (long-term trend). Likewise, consump- tion events (i.e. feasts) that bring together different local groups might act to buffer subsistence risk over the longer term. Thus while "feast-famine" is helpful in that it highlights some of the different dimensions of variation in food practices, these terms are not useful when used in opposition. Similar points have been made innumerable times with regard to ecological/social, nature/nurture, and so on.

Although the archaeological record of the Palaeolithic and Mesolithic imposes significant constraints on interpretative possibilities, much of the invisibility of food in these periods also reflects limitations of our theoretical and analytical approaches. Several researchers working with Late Upper Palaeolithic faunal assemblages have started to develop methods for examining the sociality of food consumption (e.g. Audouze and Enloe 1991; Gamble 1997). The current study of feasting at Pupicina Cave builds on these methods and provides other routes for interpretations of the archaeology of consumption during the Mesolithic, although the motives and strategies behind these Mesolithic feasts at Pupićina Cave remain obscure.

The 1995-1996 excavations at Pupićina Cave were
supported by travel grants from IREX. Kristina Miho-
vilić and the Archaeological Museum of Istria and
Ružica Vlašić provided logistical support. Special
thanks also go to Stašo Forenbaher and Snježana Vr-
doljak for assistance in the field. Laura Pugsley helped
with the coding offaunal data from the 1996 season.
The late Marija Poje identified the molluscs.

The 1995-1996 excavations at Pupicina Cave were supported by travel grants from IREX. Kristina Mihovilic and the Archaeological Museum of Istria and Ružica Vlašić provided logistical support. Special thanks also go to Stašo Forenbaher and Snježana Vr doljak for assistance in the field. Laura Pugsley helped The late Marija Poje identified the molluscs.

\section{REFERENCES}

APPADURAI A. 1981. Gastro-politics in Hindu south Asia. American Ethnologist 8: 494-511.

ARNOLD J. E. 1993. Labor and the rise of complex hunter-gatherers. Journal of Anthropological Archaeology 12: 75-119.

AUDOUZE F. \& ENLOE J. 1991. Subsistence strategies and economy in the Magdalenian of the Paris Basin, France. In N. Barton, A. J. Roberts \& D. A. Roe (eds.),
The Late Glacial in North-West Europe: Human Adaptation and Environmental Change at the End of the Pleistocene, (Council for British Archaeology Research Report 77.) London: Council for British Archaeology, 63-71.

BELOVSKY G. E. 1988. An optimal foraging-based model of hunter-gatherer population dynamics. Journal of Anthropological Archaeology 7: 329372. 
BETTINGER R. L. 1991. Hunter-Gatherers: Archaeological and Evolutionary Theory. New York (NY): Plenum Press.

BINFORD L. R. 1978. Nunamiut Ethnoarchaeology. New York (NY): Academic Press.

1981. Bones: Ancient Men and Modern Myths. New York (NY): Academic Press.

BOAS F. 1966. Kwakiutl Ethnography. H. Codere (ed.). Chicago (IL): University of Chicago Press.

BOSERUP E. 1965. The Conditions of Agricultural Growth: The Economics of Agrarian Change under Population Pressure. Chicago (IL): Aldine.

BUTZER K. W. 1982. Archaeology as Human Eco$\log y$. Cambridge: Cambridge University Press.

CODERE H. 1950. Fighting with Property: A Study of Kwakiutl Potlatching and Warfare, 1792-1930. Seattle (WA): University of Washington Press.

COHEN M. N. 1977. The Food Crisis in Prehistory. New Haven (CT): Yale University Press.

CONKEY M. 1980. The identification of prehistoric hunter-gatherer aggregation sites: the case of Altamira. Current Anthropology 21: 609-30.

1991. Contexts of action, contexts for power: material culture and gender in the Magdalenian. In J. M. Gero \& M. W. Conkey (eds.), Engendering Archaeology: Women and Prehistory: 57-92.

DIETLER M. 1996. Feasts and commensal politics in the political economy. Food, power and status in prehistoric Europe. In P. Wiessner \& W. Schiefenhövel (eds.), Food and the Status Quest, an Interdisciplinary Perspective: 87-125.

DOUGLAS M. 1972. Deciphering a meal. Deadalus 101: $61-82$.

1984. Food and the Social Order. New York (NY): Russell Sage Foundation.

ENLOE J. G. 1993. Ethnoarchaeology of marrow cracking: implications for the recognition of prehistoric subsistence organization. In J. Hudson (ed.), From Bones to Behavior: Ethnoarchaeological and Experimental Contributions to the Interpretation of
Faunal Remains, (Center for Archaeological Investigations Occasional Paper No. 21): 82-97.

ENLOE J. G. \& F. DAVID 1989. Le remontage des os par individus: le partage du renne chez les Magdaléniens de Pincevent (La Grande Paroisse, Seine-etMarne). Bulletin de la Société Préhistorique Francaise 86: 275-81.

FLANNERY K. V. 1969. Origins and ecological effects of early domestication in Iran and the Near East. In P. J. Ucko \& G. W. Dimbleby (eds.), The Domestication and Exploitation of Plants and Animals: 73100.

GAMBLE C. 1997. The animal bones from Klithi. In G. Bailey (ed.), Klithi: Palaeolithic settlement and Quaternary landscapes in northwest Greece. Vol. 1: Excavation and intra-site analysis at Klithi: $207-44$.

GOODY J. 1982. Cooking, cuisine and class. A study in comparative sociology. Cambridge: Cambridge University Press.

GOSDEN C. \& J. HATHER (eds.), 1999. The Prehistory of Food. Appetites for change. London: Routledge.

GRAYSON D. K. 1984. Quantitative Zooarchaeology. New York (NY): Academic Press.

GUMMERMAN G. IV. 1997. Food and complex societies. Journal of Archaeological Method and Theory 4: $105-39$.

HAWKES K. 1992. Sharing and collective action. In E. A. Smith \& B. Winterhalder (eds.), Evolutionary Ecology and Human Behavior: 269-300.

1993. Why hunter-gatherers work. An ancient version of the problem of public goods. Current Anthropology 34: 341-61.

HAYDEN B. 1981. Research and development in the stone age: technological transitions among hunter/ gatherers. Current Anthropology 22: 519-48.

1990. Nimrods, piscators, pluckers, and planters: the emergence of food production. Journal of $A n$ thropological Archaeology 9: 31-69.

1995. Pathways to power: principles for creating socioeconomic inequalities. In T. D. Price \& G. M. 
Feinman (eds.), Foundations of Social Inequality: 15-86.

1996. Feasting in prehistoric and traditional societies. In P. Wiessner \& W. Schiefenhövel (eds.), Food and the Status Quest, an Interdisciplinary Perspective: 127-47.

HILL K. \& KAPLAN H. 1993. On why male foragers hunt and share food. Current Anthropology 34: 701-706.

KELLY R. L. 1995. The Foraging Spectrum. Washington (DC): Smithsonian Institution Press.

KENT S. 1993. Variability in faunal assemblages: the influence of hunting skill, sharing, dogs, and mode of cooking on faunal remains at a sedentary Kalahari community. Journal of Anthropological Archaeo$\operatorname{logy} 12: 323-85$.

LANGENWALTER P E. II 1980. The archaeology of $19^{\text {th }}$ Century Chinese subsistence at the Lower China Store, Madera County, California. In R. L. Schuyler (ed.), Archaeological Perspectives of Ethnicity in America: 102-112.

LÉVI-STRAUSS C. 1969. The Raw and the Cooked. London: Jonathan Cape.

1978. The Origin of Table Manners: Introduction to a Science of Mythology, Volume 3. London: Jonathan Cape.

LUBELL D., HASSAN F. A., GAUTIER A. \& BALLAIS J.L. 1976. The Capsian escargotières. Science 191: 910-20.

LYMAN R. L. 1984. Bone density and differential survivorship of fossil classes. Journal of Anthropological Archaeology 3: 259-299.

1987. Archaeofaunas and butchery studies: a taphonomic perspective. In M. B. Schiffer (ed.), $A d$ vances in Archaeological Method and Theory, Vol. 10: 249-337.

1994. Vertebrate Taphonomy. Cambridge: Cambridge University Press.

MAREAN C. W. 1991. Measuring the postdepositional destruction of bone in archaeological assemblages. Journal of Archaeological Science 18: 677-94.
MIRACLE P. T. 1995. Broad-Spectrum Adaptations Re-examined: Hunter-Gatherer Responses to LateGlacial Environmental Changes in the Eastern Adriatic. Ph.D. Dissertation. University of Michigan. University Microfilms, Ann Arbor, MI.

1996. Diversification in Epipaleolithic subsistence strategies along the eastern Adriatic coast: a simulation approach applied to zooarchaeological assemblages. Atti del Museo Civico di Storia Naturale, Trieste IX(1994-1995): 33-62.

1997. Early Holocene foragers in the karst of northern Istria. Poročilo o raziskovanju paleolita, neolita in eneolita v Sloveniji XXIV: 43-61.

2001. Mesolithic Meals from Mesolithic Middens. In Miracle P. T. \& N. Milner (eds.), Consuming Passions and Patterns of Consumption (in press).

MIRACLE P. T. \& FORENBAHER S. 2000. Pupićina Cave Project: Brief Summary of the 1998 season. Histria Archaeologica 29(1998): 27-48.

MIRACLE P. T., GALANIDOU N. \& FORENBAHER S. 2000. Pioneers in the hills: early Mesolithic foragers at Šebrn Abri (Istria, Croatia). European Journal of Archaeology 3: 293-329.

MIRACLE P. T. \& O'BRIEN C. J. 1998. Seasonality of resource use and site occupation at Badanj, BosniaHerzegovina: subsistence stress in an increasingly seasonal environment. In T. Rocek \& 0. Bar-Yosef (eds.), Seasonality and Sedentism: Archaeological Perspectives from Old and New World Sites, (Peabody Museum Bulletin 6): 41-74.

NEELEY M. P. \& CLARK G. A. 1993. The human food niche in the Levant over the past 150000 years. In G. L. Peterkin, H. M. Bricker \& P. Mellars (eds.), Hunting and Animal Exploitation in the Later Palaeolithic and Mesolithic of Eurasia. Archaeological Papers of the American Anthropological Association No. 4: 221-240.

NOE-NYGAARD N. 1989. Man-made trace fossils on bones. Human Evolution 4: 461-91.

RENFREW J. 1996. Roman Britain. In M. Black (ed.), A Taste of History: 10,000 Years of Food in Britain: 51-93.

ROWLEY-CONWY P. \& ZVELEBIL M. 1989. Saving it for later: storage by prehistoric hunter-gatherers in 
Europe. In P. Halstead \& J. O'Shea (eds.), Bad Year Economics: Cultural Responses to Risk and Uncertainty: $40-56$.

SAMUEL D. 1996. Approaches to the archaeology of food. Petits Propos Culinaires 54: 12-21.

SOFFER 0. 1989. Storage, sedentism and the Eurasian Palaeolithic record. Antiquity 63: 719-32.

STINER M. C. 1994. Honor Among Thieves: A Zooarchaeological Study of Neandertal Ecology, Princeton (NJ): Princeton University Press.

1999. Palaeolithic mollusc exploitation at Riparo Mochi (Balzi Rossi, Italy): food and ornaments from the Aurignacian through Epigravettian. Antiquity 73: 735-54.

STINER M. C., KUHN S. L., WEINER S. \& BAR-YOSEF 0. 1995. Differential burning, recrystallization, and fragmentation of archaeological bone. Journal of Archaeological Science 22: 223-37.

STINER M. C., MUNRO N. D. \& SUROVELL T. A. 2000. The tortoise and the hare: small-game use, the broad- spectrum revolution, and Palaeolithic demography. Current Anthropology 41: 39-73.

WIESSNER P. 1996. Leveling the hunter. Constraints on the status quest in foraging societies. In P. Wiessner \& W. Schiefenhövel (eds.), Food and the Status Quest, an Interdisciplinary Perspective: 171-91.

WIESSNER P. \& SCHIEFENHÖVEL W. (eds.), 1996. Food and the Status Quest, an Interdisciplinary Perspective, Providence (RI): Berghahn.

WINTERHALDER B. 1986. Diet choice, risk, and food sharing in a stochastic environment. Journal of $A n$ thropological Archaeology 5: 369-392.

WINTERHALDER B., BAILLARGEON W., CAPPELLETTO F., DANIEL I. R. Jr. and PRESCOTT C. 1988. The population ecology of hunter-gatherers and their prey. Journal of Anthropological Archaeology 7: 289328.

YELLEN J. E. 1977. Cultural patterning in faunal remains: evidence from the !Kung Bushmen. In D. Ingersoll, J. E. Yellen \& W. Macdonald (eds.), Experimental Archaeology: 271-331. 